\title{
Adsorption of Phosphoric Acid on Niobium Oxide Coated Cellulose Fiber: Preparation, Characterization and Ion Exchange Property
}

\author{
Flávio A. Pavan ${ }^{a}$, Maria Suzana P. Francisco ${ }^{a}$, Richard Landers ${ }^{b}$ and Yoshitaka Gushikem ${ }^{*, a}$ \\ ${ }^{a}$ Instituto de Química, Universidade Estadual de Campinas, CP 6154 \\ ${ }^{b}$ Instituto de Física Gleb Wataghin, Universidade Estadual de Campinas, CP 6165 and Laboratório Nacional de Luz \\ Sincrotron, CP 6192, 13083-970 Campinas - SP, Brazil
}

\begin{abstract}
Os procedimentos para a preparação do híbrido orgânico-inorgânico celulose-óxido de nióbio $\left(\mathrm{Cel} / \mathrm{Nb}_{2} \mathrm{O}_{5}\right)$ e o seu derivado, $\mathrm{Cel} / \mathrm{Nb}_{2} \mathrm{O}_{5} /$ fosfato, são descritos. O reagente precursor do óxido metálico foi o composto oxalato de nióbio, $\left.\mathrm{NH}_{4}\left[\mathrm{NbO}\left(\mathrm{C}_{2} \mathrm{O}_{4}\right)_{2}\right)\left(\mathrm{H}_{2} \mathrm{O}\right)_{2}\right] \cdot \mathrm{nH}_{2} \mathrm{O}$, muito conveniente por ser solúvel em água. $\mathrm{O}$ íon fostato foi adsorvido sobre $\mathrm{o} \mathrm{Cel} / \mathrm{Nb}_{2} \mathrm{O}_{5}$ pela imersão deste sólido em uma solução de acido fosfórico. As análises de textura efetuadas usando a microscopia eletrônica de varredura (MEV) conectada a um detector de energia dispersiva (EDS) revelaram que as partículas do óxido de nióbio, dentro da resolução utilizada, são uniformemente dispersas na superfície da matriz de celulose. O ácido fosfórico é adsorvido sobre a superfície do material através da formação da ligação Nb-O-P. Os espectros de fotoelétrons de raios-X e de ressonância magnética nuclear de ${ }^{31} \mathrm{P}$ mostraram que o fosfato adsorvido na superfície é a espécie $\mathrm{H}_{2} \mathrm{PO}_{4}^{-}$. As isotermas de troca iônica obtidas utilizando-se o material mostraram uma boa afinidade na retenção de $\mathrm{Na}^{+}, \mathrm{K}^{+}$e $\mathrm{Ca}^{2+}$ quando em contacto com estes íons em solução aquosa.
\end{abstract}

The preparation procedures for a hybrid organic-inorganic cellulose-niobium oxide $\left(\mathrm{Cel} / \mathrm{Nb}_{2} \mathrm{O}_{5}\right)$ and its derivative, $\mathrm{Cel} / \mathrm{Nb}_{2} \mathrm{O}_{5} /$ phosphate, are described. The precursor reagent of the metal oxide was the very convenient water soluble niobium oxalate compound, $\left.\mathrm{NH}_{4}\left[\mathrm{NbO}\left(\mathrm{C}_{2} \mathrm{O}_{4}\right)_{2}\right)\left(\mathrm{H}_{2} \mathrm{O}\right)_{2}\right] \cdot \mathrm{nH}_{2} \mathrm{O}$. Phosphate ion was adsorbed on the $\mathrm{Cel} / \mathrm{Nb}_{2} \mathrm{O}_{5}$ by immersing this solid in an aqueous solution of phosphoric acid. Textural analyses carried out by using scanning electron microscopy (SEM) connected to an energy dispersive detector (EDS) revealed that the niobium oxide particles are, within the magnification used, uniformly dispersed on the cellulose matrix surface. Phosphoric acid is adsorbed on the material surface through the Nb-O-P linkage. The X-ray photoelectron and ${ }^{31} \mathrm{P}$ NMR spectra showed that the adsorbed phosphate on the surface is the $\left(\mathrm{H}_{2} \mathrm{PO}_{4}\right)^{-}$species. The ion exchange isotherms obtained using the material $\mathrm{Cel} / \mathrm{Nb}_{2} \mathrm{O}_{5} / \mathrm{H}_{2} \mathrm{PO}_{4}^{-}$showed good affinity for retaining $\mathrm{Na}^{+}$, $\mathrm{K}^{+}$and $\mathrm{Ca}^{2+}$ when in contact with these ions in an aqueous solution.

Keywords: cellulose, niobium oxide, hybrid cellulose-niobium oxide, hybrid cellulose-niobium oxide-phosphate, ion exchange

\section{Introduction}

Cellulose is a readily available natural polymer which has been widely used as a substrate for reagent immobilization, having numerous applications, such as optical biosensors, ${ }^{1}$ ion exchangers, ${ }^{2}$ support for immobilization of microorganisms, ${ }^{3}$ adsorbent for extraction of heavy metals ${ }^{4}$ and organic pollutants, ${ }^{5}$ and to support electroactive chemical species for use as an electrochemical sensor. ${ }^{6}$ The polymer is relatively inert because the hydroxyl groups, which are responsible for

*e-mail: gushikem@iqm.unicamp.br the majority of the reactions with organic or inorganic reagents, are involved in inter- and intramolecular hydrogen bonds. ${ }^{7,8}$ Although the modification of the cellulose surface is not easy, considering its relatively low reactivity, some procedures involving metal oxide coating of the surface have been reviewed. ${ }^{9}$

The experimental methodology of the fiber coating process depends on the form in which the cellulose is obtained, fiber or membrane. In the fiber form, the treatment of cellulose with a precursor reagent can be made in an aqueous or non-aqueous solvent. We have described the preparation of cellulose niobium oxide $\left(\mathrm{Cel} / \mathrm{Nb}_{2} \mathrm{O}_{5}\right)$ in a non-aqueous solvent using $\mathrm{NbCl}_{5}$ as the precursor 
reagent. ${ }^{10}$ However, strong Lewis acids such as $\mathrm{MCl}_{\mathrm{n}}$ $(\mathrm{M}=\mathrm{Ti}(\mathrm{IV}), \mathrm{Nb}(\mathrm{V})$ and $\mathrm{Zr}(\mathrm{IV}))$ attack the ring of the glucosidic $\mathrm{C}-\mathrm{O}-\mathrm{C}$ bonds, promoting their rupture due to $\mathrm{C}-\mathrm{O}-\mathrm{M}$ bond formation. ${ }^{11}$ This rupture results in extensive degradation of the macromolecular chain, which may not be convenient.

In order to avoid this extensive degradation of the cellulose structure, surface coating using hydrated metal precursors has also been developed. This method of coating consists in immersing the cellulose fiber in an aqueous solution of the metal ion of interest, followed by complete evaporation of the solvent to dryness. ${ }^{12}$ It has been observed that the degree of adhesion of the metal oxide layers depends on the degree of dispersion of the hydrated metal oxide and its thickness on the cellulose surface. ${ }^{13-16}$

Among the metal oxides, $\mathrm{Nb}_{2} \mathrm{O}_{5}$ coated solid substrate surfaces have merited considerable attention, in view of the local structure of the oxide particles, ${ }^{17-20}$ its properties and potential applications. ${ }^{21}$ Furthermore, the additional adsorption of phosphoric acid on a surface containing the oxide can considerably increase the surface acidity, which may be useful in heterogeneous catalytic reactions and in ion exchange. ${ }^{22-24}$

In the present work, we describe the preparation of $\mathrm{Cel} /$ $\mathrm{Nb}_{2} \mathrm{O}_{5}$ /phosphate using a water-soluble niobium ammonium oxalate complex, $\mathrm{NH}_{4}\left[\mathrm{NbO}\left(\mathrm{C}_{2} \mathrm{O}_{4}\right)_{2}\left(\mathrm{H}_{2} \mathrm{O}\right)_{2}\right]$, as the precursor reagent. The advantage in using this precursor is its solubility in water. The reactions are carried under very mild conditions. The hybrid material obtained, Cel/ $\mathrm{Nb}$ /phosphate, was characterized by scanning electron microscopy, X-ray photoelectron spectroscopy, and solid state ${ }^{31} \mathrm{P}$ NMR techniques. The facility of the material obtained for retaining $\mathrm{Na}^{+}, \mathrm{K}^{+}$and $\mathrm{Ca}^{2+}$ ions in aqueous solution was evaluated.

\section{Experimental}

\section{Preparation of the Cel/ $/ \mathrm{Nb}_{2} \mathrm{O}_{5}$ hybrid material}

Samples presenting variable amounts of niobium oxide in the $\mathrm{Cel} / \mathrm{Nb}_{2} \mathrm{O}_{5}$ hybrid materials were prepared. In a typical procedure $20 \mathrm{~g}(0.04 \mathrm{~mol})$ of niobium ammonium oxalate complex, $\mathrm{NH}_{4}\left[\mathrm{NbO}\left(\mathrm{C}_{2} \mathrm{O}_{4}\right)_{2}\left(\mathrm{H}_{2} \mathrm{O}\right)_{2}\right] \cdot \mathrm{nH}_{2} \mathrm{O}$ (supplied by Companhia Brasileira de Metalurgia e Mineração, Brazil) was dissolved in $200 \mathrm{~mL}$ of distilled water and $10 \mathrm{~g}$ of cellulose microfibers (Sigma) were immersed in this solution. The solvent was slowly evaporated at $353 \mathrm{~K}$ and the resulting wet sample was submitted to a saturated $\mathrm{NH}_{3}$ gas atmosphere for $30 \mathrm{~min}$. The solid after this treatment was exhaustively washed with distilled water and then the residual solvent was removed under vacuum $\left(10^{-3}\right.$ torr) at room temperature. The preparation was repeated, using the same procedure, but changing the amount of the starting metal oxide precursor reagent, i.e, 5.1 and $10 \mathrm{~g}$ of niobium ammonium oxalate complex.

The quantities of $\mathrm{Nb}_{2} \mathrm{O}_{5}$ dispersed onto the hybrid material, $\mathrm{Cel} / \mathrm{Nb}_{2} \mathrm{O}_{5}$, was determined by heating $0.5 \mathrm{~g}$ of $\mathrm{Cel} / \mathrm{Nb}_{2} \mathrm{O}_{5}$ at $1273 \mathrm{~K}$ for $2 \mathrm{~h}$ in an air atmosphere.

The amount of $\mathrm{H}_{3} \mathrm{PO}_{4}$ adsorbed on the $\mathrm{Cel} / \mathrm{Nb}_{2} \mathrm{O}_{5}$ surface was determined from an adsorption isotherm obtained at $298 \mathrm{~K}$. About $0.1 \mathrm{~g}$ of $\mathrm{Cel} / \mathrm{Nb}_{2} \mathrm{O}_{5}$ was immersed in $25.0 \mathrm{~mL}$ of $\mathrm{H}_{3} \mathrm{PO}_{4}$ solutions (concentrations between $10^{-5}$ and $10^{-3} \mathrm{~mol} \mathrm{~L}^{-1}$ ) and the suspensions shaken for $12 \mathrm{~h}$ at $298 \mathrm{~K}$. The quantity of phosphoric acid adsorbed on $\mathrm{Cel} / \mathrm{Nb}_{2} \mathrm{O}_{5}$ along the isotherm curve was determined by applying the equation:

$N_{f}=\frac{N_{a}-N_{s}}{m}$

where $\mathrm{N}_{\mathrm{a}}$ is the initial mole number of phosphoric acid added into the reaction flask, $\mathrm{N}_{\mathrm{s}}$ is the equilibrium mole number of the phosphoric acid in the solution phase in equilibrium with the solid phase and $m$ is the mass of the adsorbent. The experiment was carried out by the batch procedure and the analysis of the phosphate ion in the solution phase was made by the spectrophotometric method. ${ }^{25}$

\section{Ion exchange experiments}

The ion exchange isotherms using the $\mathrm{Cel} / \mathrm{Nb}_{2} \mathrm{O}_{5} /$ phosphate as adsorbent of $\mathrm{Ca}^{+2}, \mathrm{~K}^{+}$and $\mathrm{Na}^{+}$were obtained at $298 \mathrm{~K}$ using the batch technique. About $100 \mathrm{mg}$ of the adsorbent were immersed in $25 \mathrm{~mL}$ of metal chloride solutions, whose concentrations varied between $10^{-3}$ at $10^{-4} \mathrm{~mol} \mathrm{~L}^{-1}$, and the resulting suspensions were orbitally shaken for $6 \mathrm{~h}$. The metal ions in the supernatant solutions were separated by decanting from the solid phase and their concentrations determined by inductive coupled plasma (ICP) optical emission spectroscopy (OES) on a PerkinElmer 3000 DV ICP optical emission spectrometer. The quantities of the exchanged metals were determined by applying equation (1).

\section{Characterization}

The scanning electron microscopy (SEM) images were obtained for samples dispersed on a double face conducting tape on an aluminum support and coated with a thin film of gold (ca. $15 \mathrm{~nm}$ ) using a BalTec SCD 050 Sputter Coater apparatus (60 mA current for $60 \mathrm{~s}$ ). The micrograph was 
obtained using a JSM 5900LV microscope connected to a secondary electron detector and X-ray energy dispersive spectrometer (EDS) for elemental mapping in a Noram Voyager instrument.

The ${ }^{31} \mathrm{P}$ cross polarization magic angle spinning magnetic resonance (CPMAS NMR) spectrum of the sample was obtained at room temperature on a Bruker ACP300 spectrometer operating at $121 \mathrm{MHz}$. A sequential pulse with a contact time of $1 \mathrm{~ms}, 2$ s interval between pulses and an acquisition time of $11 \mathrm{~ms}$ was used. Standard phosphoric acid ( $85 \mathrm{wt} \%$, Aldrich) was used as reference.

The X-ray photoelectron spectra of the prepared materials were obtained with an HA100 VSW hemispherical analyzer operated in the fixed transmission mode. The high resolution spectra were measured with constant analyzer pass energies of $44 \mathrm{eV}$, which produce a FWHM line width of $1.8 \mathrm{eV}$ for the Au $4 f_{7 / 2}$ line. Charging effects were corrected by shifting the spectra linearly so that the $\mathrm{C} 1 s$ line had a binding energy of $284.6 \mathrm{eV},{ }^{17}$ the absolute energy for the internal reference.

\section{Results and Discussion}

\section{Characterization of the composites}

The amounts of $\mathrm{Nb}_{2} \mathrm{O}_{5}$ determined in $\mathrm{Cel} / \mathrm{Nb}_{2} \mathrm{O}_{5}$ are listed in Table 1. The quantities of niobium oxide obtained (in mmol of niobium per gram of the material) are 0.049 , 0.13 and 0.61 .

Table 1. Amount of $\mathrm{Nb}_{2} \mathrm{O}_{5}$ on the cellulose $\mathrm{e}^{\mathrm{a}}$ fiber surface

\begin{tabular}{lcc}
\hline Samples & Precursor reagent $(\mathrm{g})$ & $\mathrm{Nb}_{2} \mathrm{O}_{5}(\mathrm{wt} \%)$ \\
\hline $\mathrm{A}$ & 5.1 & 1.3 \\
$\mathrm{~B}$ & 10.0 & 3.6 \\
$\mathrm{C}$ & 21.0 & 8.1 \\
\hline
\end{tabular}

amount of cellulose: $20 \mathrm{~g}$ for all preparations.

The amount of $\mathrm{Nb}_{2} \mathrm{O}_{5}$ coated for samples $\mathrm{A}$ and $\mathrm{B}$ in Table 1 is very small compared with sample $\mathrm{C}$. The adsorption isotherm viewing determination of phosphoric acid adsorbed on the $\mathrm{Cel} / \mathrm{Nb}_{2} \mathrm{O}_{5}$ surface was determined only for sample $\mathrm{C}, \mathrm{Cel} / 8.1 \% \mathrm{Nb}_{2} \mathrm{O}_{5}$, since for samples $\mathrm{A}$ and $\mathrm{B}$, containing $1.3 \%$ and $3.6 \%$ of $\mathrm{Nb}_{2} \mathrm{O}_{5}$, the amount of adsorbed phosphoric acid was very small and not useful as an ion exchanger material.

Figure 1 shows the adsorption isotherm of $\mathrm{H}_{3} \mathrm{PO}_{4}$ on the $\mathrm{Cel} / \mathrm{Nb}_{2} \mathrm{O}_{5}$ surface, determined at $298 \mathrm{~K}$. In this case, the adsorption process may occur by the reaction of $\mathrm{H}_{3} \mathrm{PO}_{4}$ and the niobium reactive center, designated as $\mathrm{Nb}-\mathrm{OH}$, according to the following reaction:
$\mathrm{nNb}-\mathrm{OH}_{\text {(sol) }}+\mathrm{H}_{3} \mathrm{PO}_{4(\mathrm{aq})} \leftrightarrows(\mathrm{Nb}-\mathrm{O})_{\mathrm{n}} \mathrm{PO}(\mathrm{OH})_{3-\mathrm{n}(\mathrm{sol})}+\mathrm{nH}_{2} \mathrm{O}_{(\text {aq })}$

where sol and aq are the solid and solution phases, respectively. At the saturation condition on the isotherm curve, the adsorption capacity of phosphoric acid was 0.30 mmol g-1.

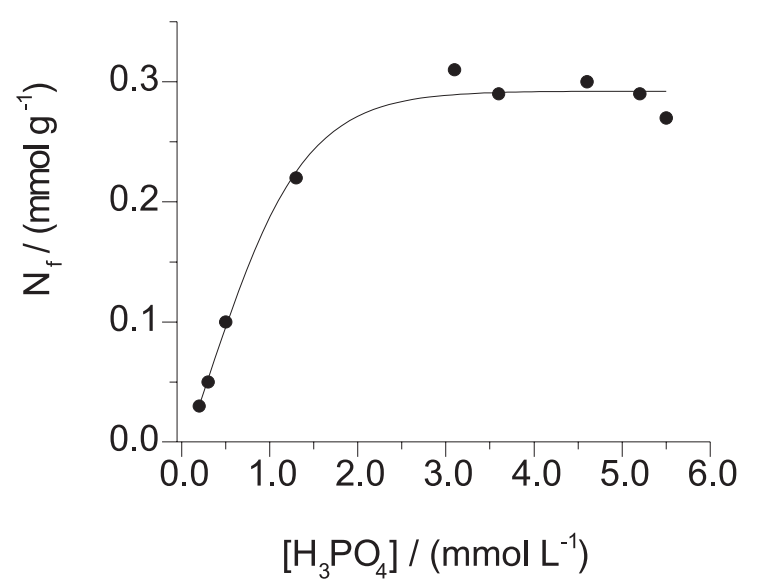

Figure 1. Adsorption isotherm of $\mathrm{H}_{3} \mathrm{PO}_{4}$ on $\mathrm{Cel} / 8.1 \% \mathrm{Nb}_{2} \mathrm{O}_{5}$ at $298 \mathrm{~K}$.

Texture of the $\mathrm{Cel} / \mathrm{Nb}_{2} \mathrm{O}_{5}$ phosphate surface

Figure 2 shows the SEM and the corresponding EDS image for Cel/ $/ \mathrm{Nb}_{2} \mathrm{O}_{5}$ /phosphate. Figure 2a show a fiber with a uniform surface, without specific definition within the magnification used. For the EDS image in Figure 2b, the bright points on the surface are due to the characteristic emission of the $\mathrm{Nb} \mathrm{L} \alpha \mathrm{X}$-ray $(2.17 \mathrm{eV})$. The metal mapping shows that niobium oxide, within the magnification used, uniformly covers the fiber surface with no detectable agglomerated particles of the oxide on the cellulose surface. The $\mathrm{P}$ emission line was not observed since its concentration is below the detection limit of the equipment. However, assuming that $\mathrm{P}$ is adsorbed onto the substrate surface through a $\mathrm{Nb}-\mathrm{O}-\mathrm{P}$ linkage, it is reasonable to assume that it is also well dispersed on the surface as niobium phosphate particles.

\section{XPS data}

Figures 3 and 4 show the XPS $\mathrm{O} 1 \mathrm{~s}$ and $\mathrm{Nb} 3 \mathrm{~d}$ lines, respectively, for $\mathrm{Cel} / \mathrm{Nb}_{2} \mathrm{O}_{5}, \mathrm{Cel} / \mathrm{Nb}_{2} \mathrm{O}_{5} /$ phosphate and pure cellulose. Table 2 summarizes the XPS binding energies (BE) found and the $\mathrm{P} / \mathrm{Nb}$ atomic ratios calculated (error ca. $8 \%$ ) for the materials.

Figure 3a shows the O 1s (BE) peak at $532.9 \mathrm{eV}$ associated with pure cellulose, designated as $\mathrm{O}^{1}$. Upon modification of the surface by coating with metal oxide (Figure $3 b$ ) and subsequent reaction with $\mathrm{H}_{3} \mathrm{PO}_{4}$ (Figure 
3c), the $\mathrm{O} 1 \mathrm{~s} \mathrm{BE}$ does not change. For $\mathrm{Nb}_{2} \mathrm{O}_{5}$ the $\mathrm{O} 1 \mathrm{~s} \mathrm{BE}$ designated as $\mathrm{O}^{2}$, is observed at $530.6 \mathrm{eV}$ while in the oxide dispersed on the cellulose surface, $\mathrm{Cel} / \mathrm{Nb}_{2} \mathrm{O}_{5}$, the energy is observed at $530.4 \mathrm{eV}$. The results indicate that the interaction of the cellulose with the metal oxide is weak, presumably by a hydrogen bonding $-\mathrm{OH} \cdots \mathrm{ONb}$, where $-\mathrm{OH}$ refers to the cellulose hydroxyl group. ${ }^{26}$

The pure oxide shows the $\mathrm{Nb} 3 \mathrm{~d}_{5 / 2} \mathrm{BE}$ at $207.4 \mathrm{eV}$. By dispersing the niobium oxide onto the cellulose surface in $\mathrm{Cel} / \mathrm{Nb}_{2} \mathrm{O}_{5}$ the same spin orbit component is observed at
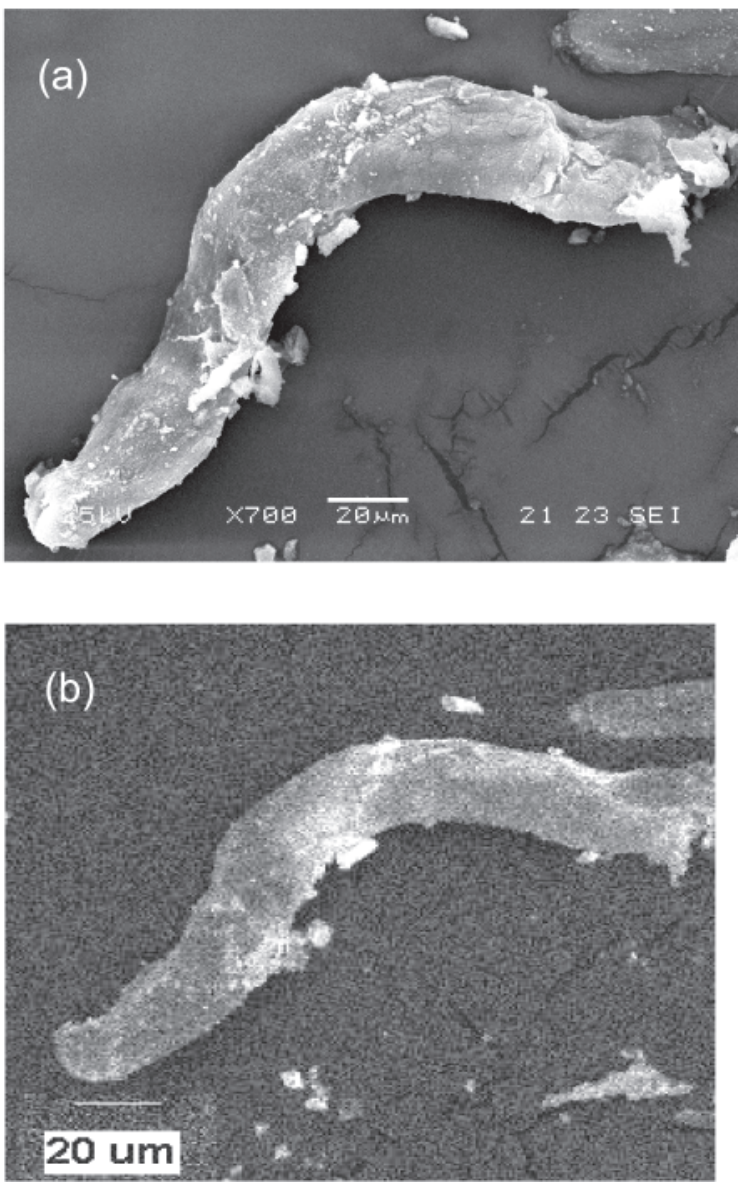

Figure 2. SEM image for (a) $\mathrm{Cel} / 8.1 \% \mathrm{Nb}_{2} \mathrm{O}_{5} /$ phosphate and (b) the corresponding EDS mapping.

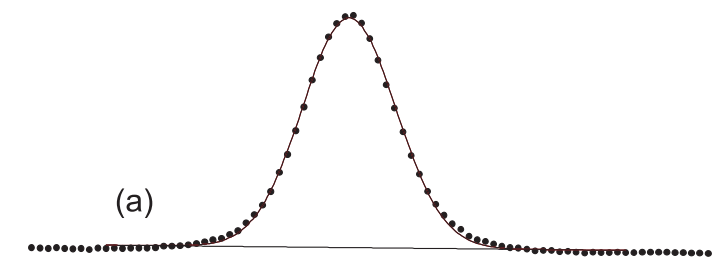

(b)
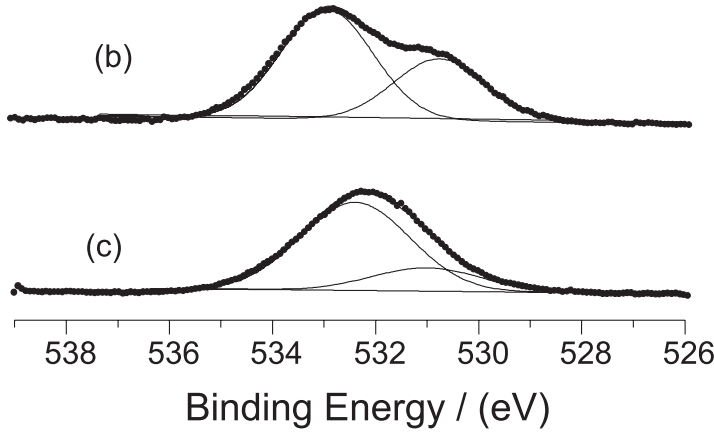

Figure 3. XPS O1s BE peaks of (a) pure cellulose, (b) $\mathrm{Cel} / 8.1 \% \mathrm{Nb}_{2} \mathrm{O}_{5}$ and (c) $\mathrm{Cel} / 8.1 \% \mathrm{Nb}_{2} \mathrm{O}_{5} /$ phosphate.

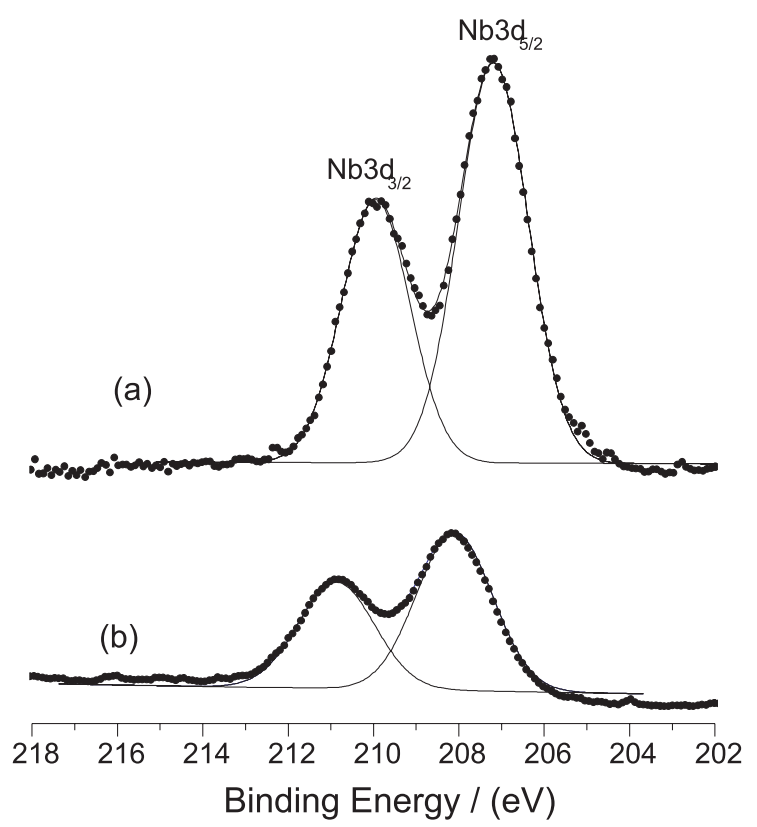

Figure 4. XPS $\mathrm{Nb} 3 \mathrm{~d}$ BE peaks of (a) $\mathrm{Cel} / 8.1 \% \mathrm{Nb}_{2} \mathrm{O}_{5}$ and (b) $\mathrm{Cel} /$ $8.1 \% \mathrm{Nb}_{2} \mathrm{O}_{5} /$ phosphate.

Table 2. Binding energies $(\mathrm{eV})$ for $\mathrm{Cel} / \mathrm{Nb}_{2} \mathrm{O}_{5}$ and $\mathrm{Cel} / \mathrm{Nb}_{2} \mathrm{O}_{5} /$ phosphate

\begin{tabular}{|c|c|c|c|c|c|}
\hline \multirow[t]{2}{*}{ Samples } & \multicolumn{2}{|c|}{$\mathrm{O} 1 \mathrm{~s}$} & \multirow[t]{2}{*}{$\mathrm{Nb} 3 \mathrm{~d}_{5 / 2}$} & \multirow[t]{2}{*}{ P $2 p$} & \multirow[t]{2}{*}{$\mathrm{P} / \mathrm{Nb}$} \\
\hline & $\mathrm{O}^{1}$ & $\mathrm{O}^{2}$ & & & \\
\hline Cellulose & $532.9(2.1)^{\mathrm{b}}$ & - & - & - & - \\
\hline $\mathrm{Cel} / \mathrm{Nb}_{2} \mathrm{O}_{5}$ & $532.5(2.1)$ & $530.4(2.1)$ & $207.2(1.9)$ & - & - \\
\hline $\mathrm{Cel} / \mathrm{Nb}_{2} \mathrm{O}_{5} /$ phosphate & $532.4(2.5)$ & $531.0(2.5)$ & $208.1(2.1)$ & $134.2(2.4)$ & 2.1 \\
\hline $\mathrm{Nb}_{2} \mathrm{O}_{5}{ }^{\mathrm{a}}$ & - & 530.6 & 207.4 & - & - \\
\hline $\mathrm{Na}_{3} \mathrm{PO}_{4}{ }^{\mathrm{a}}$ & - & - & - & 132.4 & - \\
\hline $\mathrm{Na}_{2} \mathrm{HPO}_{4}{ }^{\mathrm{a}}$ & - & - & - & 133.1 & - \\
\hline $\mathrm{NaH}_{2} \mathrm{PO}_{4}{ }^{\mathrm{a}}$ & - & - & - & 134.2 & - \\
\hline
\end{tabular}

Ref. 24; ' $\mathrm{HHPW}$ (half height peak width). 
$207.2 \mathrm{eV}$. This result indicates that the dispersion of the oxide followed by its adhesion onto the cellulose surface does not affect the energy value. This result confirms the conclusion above that the interaction of the oxide and the cellulose is weak. Upon absorption of the phosphoric acid on the matrix surface the $\mathrm{Nb} 3 \mathrm{~d}_{5 / 2} \mathrm{BE}$ is shifted to $208.1 \mathrm{eV}$ (Figure 4) due to interaction of the acid with $\mathrm{Nb}$ on the surface, forming of the Nb-O-P linkage. In this case, the observed BE shift is associated with a change in the $\mathrm{Nb}-\mathrm{O}$ bond polarization, which normally shifts this energy to a higher value. ${ }^{18,27}$ The $\mathrm{P} 2 \mathrm{p}$ BE for the adsorbed phosphate is observed at $134.2 \mathrm{eV}$ (Table 2) and by comparing this with those listed for $\mathrm{Na}_{3} \mathrm{PO}_{4}, \mathrm{Na}_{2} \mathrm{HPO}_{4}$ and $\mathrm{NaH}_{2} \mathrm{PO}_{4}, 132.4$, 133.1 and $134.2 \mathrm{eV}$, respectively, ${ }^{28}$ it is possible to conclude that the species adsorbed onto the niobium atom is the $\mathrm{H}_{2} \mathrm{PO}_{4}$ - species. $^{29,30}$ The adsorbed phosphate species are mainly located at the surface since the atomic ratio $\mathrm{P} /$ $\mathrm{Nb}=2.1$ (Table 1) while that calculated considering the bulk is an atomic ratio $\mathrm{P} / \mathrm{Nb}=0.46$.

To give support to our conclusion, the ${ }^{31} \mathrm{P}$ NMR spectrum of $\mathrm{Cel} / \mathrm{Nb}_{2} \mathrm{O}_{5}$ /phosphate was also obtained. The spectrum shows (Figure 5) a broad peak centered at $c a-3 \mathrm{ppm}$, which is consistent with the $\mathrm{H}_{2} \mathrm{PO}_{4}^{-}$species ${ }^{29}$ and the mode of its coordination to the metal is described as $(\mathrm{Nb}-\mathrm{O})-\mathrm{PO}(\mathrm{OH})_{2}$.

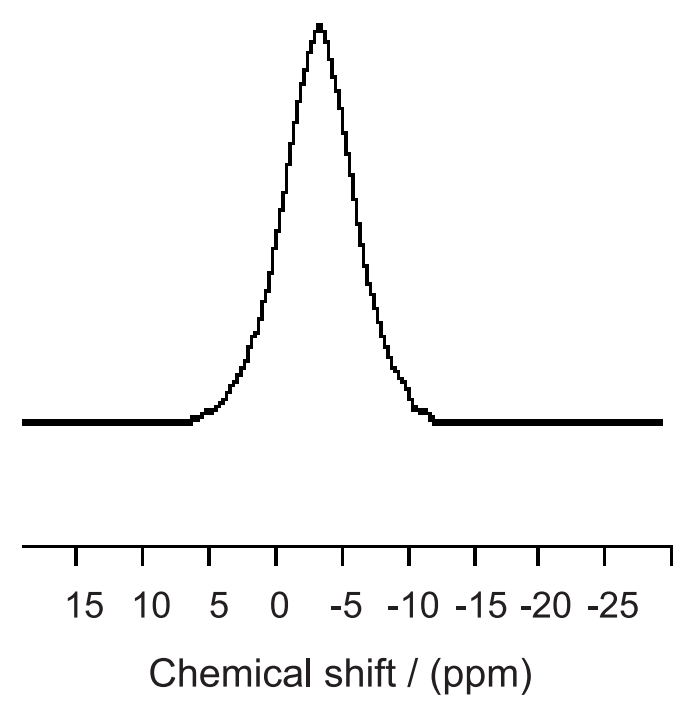

Figure 5. ${ }^{31} \mathrm{P}$ CPMAS NMR spectrum of $\mathrm{Ce} / / 8.1 \% \mathrm{Nb}_{2} \mathrm{O}_{5} /$ phosphate. Ions exchange reactions

Niobium hydrogen phosphate is described as a strong $\mathrm{Br} \phi$ nsted solid $\mathrm{acid}^{24}$ and, thus, it may be very convenient to use as an adsorbent of certain cations, such as $\mathrm{Na}^{+}, \mathrm{K}^{+}$and $\mathrm{Ca}^{2+}$, from an aqueous solutions. In the present case its use dispersed on a cellulose fiber is of considerable interest, since bulk niobium phosphate normally is obtained as a fine powder presenting low mechanical resistance, a difficult to handle. ${ }^{31}$ Such characteristics impose restrictions on its use as a packing material in a chromatographic column or as membrane in separation processes.

In the present case the cellulose modified fiber showed high flexibility allied with good mechanical resistance. As the niobium phosphate is dispersed as a thin layer on the fiber surface, no leaching of the solid acid to the solution phase was detected during the ion exchange experiments carried out by the batch technique. The ion exchange isotherm obtained for $\mathrm{Na}^{+}, \mathrm{K}^{+}$and $\mathrm{Ca}^{+2}$ is presented in Figure 6.

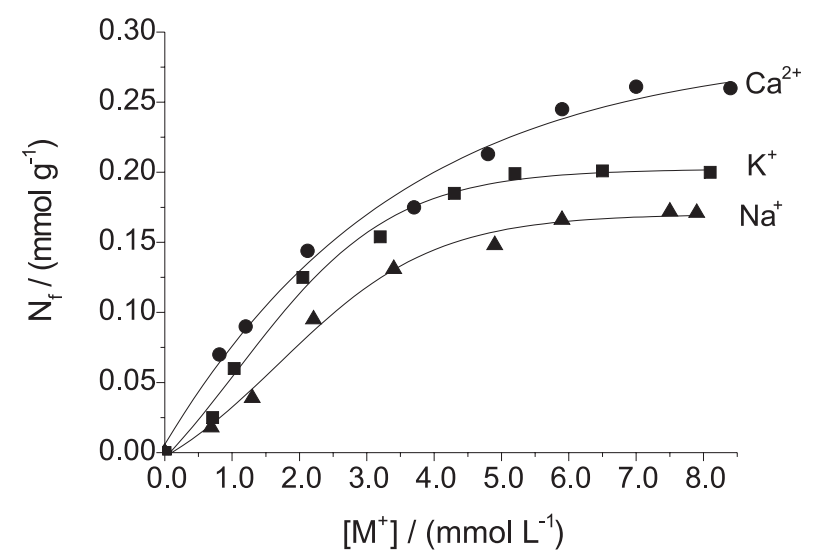

Figure 6. Ion exchange isotherms of $\mathrm{Ca}^{2+}, \mathrm{K}^{+}$and $\mathrm{Na}^{+}$on $\mathrm{Cel} /$ $8.1 \% \mathrm{Nb}_{2} \mathrm{O}_{5} /$ phosphate from aqueous solutions at $298 \mathrm{~K}$.

The adsorption capacity (designated as $\mathrm{N}_{\mathrm{f}}^{0}$ ) for each ion was experimentally determined at limit of saturation condition from the isotherm of each ion. The following values of $\mathrm{N}_{\mathrm{f}}^{0}$ were found (in $\mathrm{mmol} \mathrm{g} \mathrm{g}^{-1}$ ): $\mathrm{Ca}^{2+}=0.26$, $\mathrm{K}^{+}=0.20$ and $\mathrm{Na}^{+}=0.17$, with a standard deviation of $3.6 \%$ for each ion.

From the ion exchange isotherms obtained for $\mathrm{Ca}^{2+}, \mathrm{K}^{+}$ and $\mathrm{Na}^{+}$, using the $\mathrm{Ce} 1 / 8.1 \% \mathrm{Nb}_{2} \mathrm{O}_{5} /$ phosphate, the distribution coefficients $\left(D=N_{f} / C\right)$, were $C$ is the metal ion concentration on solution phase in equilibrium with the solid phase, were estimated for half occupation of the surface by the metal ions (mole fraction $\mathrm{X}=0.5$ or 0.15 mmol of the metal per gram of the solid) showed the following values (in $\mathrm{mL} \mathrm{g}^{-1}$ ): $\mathrm{Ca}^{2+}=75, \mathrm{~K}^{+}=54$ and $\mathrm{Na}^{+}=34$. The affinity order observed $\mathrm{Ca}^{2+}>\mathrm{K}^{+}>\mathrm{Na}^{+}$can be explained by the increase in the strength of the electrostatic interaction between the hydrated cations and the fixed anionic groups. The strength of the electrostatic interaction is larger between $\mathrm{Ca}^{2+}$ and the fixed phosphate because of the larger charge of the alkaline earth metal compared with both alkaline metals. The larger affinity for $\mathrm{K}^{+}$in comparison with $\mathrm{Na}^{+}$is due to the sizes (in $\mathrm{nm}$ ) of the hydrated cations, i.e.: $\mathrm{K}^{+}=0.24$ and $\mathrm{Na}^{+}=0.36$. The 
electrostatic interaction strength increase with a decrease of hydrated ionic radii of the cations.

These values indicate that the modified solid substrate surface shows a reasonably affinity for these ions from the solution phase.

\section{Conclusions}

The hybrid material $\mathrm{Cel} / \mathrm{Nb}_{2} \mathrm{O}_{5}$, prepared by using $\mathrm{NH}_{4}\left[\mathrm{NbO}\left(\mathrm{C}_{2} \mathrm{O}_{4}\right)_{2}\left(\mathrm{H}_{2} \mathrm{O}\right)_{2}\right] \cdot \mathrm{nH}_{2} \mathrm{O}$ as the precursor reagent, allowed obtaining the metal oxide $\mathrm{Nb}_{2} \mathrm{O}_{5}$ as well dispersed particles on a cellulose surface. The SEM image and the metal mapping with EDS technique, within the magnification used, did not detect any formation of isolated oxide particle islands.

Adsorption of phosphoric acid occurred on the surface by forming the species $\mathrm{Nb}-\mathrm{O}-\mathrm{PO}(\mathrm{OH})_{2}$. The distribution coefficients D obtained by ion exchange isotherms estimated for half occupation of the surface by the metal ions (mole fraction $\mathrm{X}=0.5$ or $0.15 \mathrm{mmol}$ of the metal per gram of the solid) showed the following values (in $\mathrm{mL}$ $\left.\mathrm{g}^{-1}\right): \mathrm{Ca}^{2+}=75, \mathrm{~K}^{+}=54$ and $\mathrm{Na}^{+}=34$.

\section{Acknowledgments}

F.A.P. and M.S.P.F. are indebted to FAPESP for postdoctoral fellowships. Y.G. and R.L. acknowledge financial support from FAPESP and CNPq-PRONEX. The authors wish to acknowledge Prof. Carol H. Collins (IQ-UNICAMP) for manuscript revision and Rita de C. G. Vinhas for technical assistance. The research work was partially performed at LME of the National Synchrotron Light Laboratory (LNLS), Brazil.

\section{References}

1. Löscher, F.; Ruckstuhl, T; Jaworek T, Wegner, G; Seeger, S.; Langmuir 1998,14, 2786.

2. Lederer, M.; Anal Chim Acta 1998, 364, 3.

3. Sakurai, A; Itoh, M.; Sakakibara, M.; Saito, H; Fujita, M.; J. Chem. Technol. Biotechnol. 1997, 70, 157.

4. Waly, A.; Abdel-Mohdy, F.A.; Aly, A.S.; Hebeich, A.; J. Appl. Polym. Sci. 1998, 68, 2151.

5. Chung, T.S.; Loh, K.; Goh, S. K.; J. Appl. Polym. Sci. 1998, $68,1677$.

6. Gushikem, Y.; Campos, E.A.; J. Braz. Chem. Soc. 1998, 9 , 273.

7. Shisonok, MV.; Gert, E.V.; Filanchuk, T.I.; Kaputskii, F.N.; J. Appl. Chem. 1987, 60,1086.

8. Ivanova, N.Y.; Korolenko, E.A.; Korolik, E.V.; Zhbankov, R.G.; J. Appl. Spectrosc. 1989, 52, 847.
9. Gushikem, Y.; Toledo, E.A. In Polymer Interfaces and Emulsions; Esumi, K.,ed., Marcel Dekker: New York, 1999, ch.13, p. 509.

10. Campos, E.A.; Gushikem, Y.; Gonçalves, M.C.; Castro, S.C.; J. Colloid Interface Sci. 1996, 180, 453.

11. Afanasev, V.A.; Sarybaeva, A.S.; Sultankulova, A.S.; Vasilikova, T.V.; Pure Appl. Chem. 1989, 61, 1993.

12. Suzuki, M.; Fujii. T. In New Developments in Ion Exchange Materials. Fundamentals and Applications; Abe, M.; Kataoka, T.; Suzuki, T., eds., Elsevier: Tokyo, 1991, p. 355.

13. Lazarin, A.M.; Gushikem, Y.; Castro, S.C.; J. Mater. Chem. 2000, 10, 2526

14. Lazarin, A.M.; Landers, R.; Kholin, Y.V., Gushikem, Y.; J. Colloid Interface Sci. 2002, 25, 31.

15. Lazarin, A.M.; Gushikem, Y.; J. Braz. Chem. Soc. 2002, 13, 88.

16. Borgo, C.A.; Lazarin, A.M.; Kholin, Y.V.; Landers, R., Gushikem Y.; J. Braz Chem. Soc. 2004, 15, 50.

17. Francisco, M. S. P.; Gushikem, Y.; J. Mater. Chem. 2002, 12, 2252.

18. Francisco, M. S. P.; Landers, R.; Gushikem, Y.; J. Solid. State. Chem. 2004, 177, 2431.

19. Ichikuni, N.; Shirai, M.; Iwasawa. Y.; Catal. Today 1996, 28, 49.

20. Ichikuni, N.; Iwasawa, Y.; Catal. Today 1993, 16, 427.

21. Nowak, I.; Ziolek, M.; Chem. Rev. 1999, 99, 3603.

22. Ziolek, M.; Catal. Today 2003, 78, 47.

23. Mal, N. K.; Bhaumir, A.; Kumar, P.; Fujiwara, M.; Chem. Commun. 2003, 872.

24. Armaroli, T.; Busca, G.; Carlini, C.; Giuttari, M.; Galleta. A. M. R.; Sbrana, G.; J. Mol. Catal. 2000, 151, 233.

25. Marczenko, Z.; Spectrophotometric Determination of Elements, Ellis Horwood: Chichester, 1976, p. 616.

26. Rodrigues-Filho, U. P.; Gushikem, Y; Gonçalves, M. C.; Cachichi, R. C.; Castro, S. C.; Chem. Mater. 1996, 8,1375.

27. Alberti, G.C.; Marletta, U.; Puglisi, G.O.; Pignataro, S.; J. Inorg. Nucl. Chem. 1981, 43, 3329.

28. Chastain, J., ed.; Handbook of X-Ray Photoelectron Spectroscopy, Perkin Elmer: Minnesota, 1992.

29. Chung, S. H.; Wang, Y.; Greenbaum, S. G.; Bzducha, W.; Zukowska, G.; Wieczorek, W.; Electrochim. Acta 2001, 46, 1651 .

30. Alfaya, A. A. S.; Gushikem, Y; Castro, S. C.; Microp. Mesop. Mater. 200, 39, 57.

31. Rodrigues-Filho, U. P.; Gushikem, Y.; Gonçalves, M. C.; Cachichi, R. C.; Castro, S.C.; Chem. Mater. 1996, 8, 1375.

Received: October 22, 2004 Published on the web: May 20, 2005

FAPESP helped in meeting the publication costs of this article. 